\title{
Barkoding DNA pada Tumbuhan Durik-Durik (Syzygium sp.) Asal Riau Menggunakan Daerah Gen $n d h F$
}

\section{(DNA Barcoding on Durik-durik (Syzygium sp.) Origin Riau Using ndhF Gene Region)}

\author{
Dewi Indriyani Roslim ${ }^{*}$, Ana Fitriani \\ Jurusan Biologi FMIPA Universitas Riau, Jl. HR Soebrantas Km 12,5 Kampus Bina Widya, Panam, \\ Pekanbaru 28293, Riau \\ *Email: iinroslim@gmail.com
}

(Article History: Received 11 November 2020; Revised 9 January 2021; Accepted 18 January 2021)

\begin{abstract}
ABSTRAK
Gen ndhF telah digunakan sebagai salah satu barkode DNA pada genus Syzygium karena divergensi urutan asam aminonya lebih besar empat kali dibandingkan rbcL. Penelitian ini bertujuan menganalisis sekuen DNA dari gen ndhF pada durik-durik (Syzygium sp.) asal Riau. Metode penelitian meliputi isolasi DNA total menggunakan kit isolasi DNA (Genomic DNA Mini Kit Plant, Geneaid), PCR, elektroforesis menggunakan $1 \%$ gel agarosa, sekuensing dan analisis data menggunakan program BioEdit versi 7, BLASTn dan MEGA 6.0. Sekuen DNA dari gen ndhF durik-durik telah diperoleh dengan ukuran $1370 \mathrm{pb}$ dan memiliki kemiripan paling tinggi dengan yang dimiliki oleh $S$. malaccense $(99,71 \%)$ dan paling rendah dengan S. acuminatissimum $(98,69 \%)$. Terdapat 26 variasi nukleotida di antara aksesi yang diteliti dan dua diantaranya merupakan nukleotida kritis. Durik-durik membentuk satu kelompok dengan $S$. malaccense dan S. aromaticum. Namun demikian, nama spesies durik-durik belum dapat ditentukan karena tidak ada aksesi yang memiliki kemiripan 100\% dengan durik-durik.
\end{abstract}

Kata kunci: Barkode DNA, Danau Kajuik, durik-durik, gen ndhF, Syzygium.

ABSTRACT
The ndhF gene has been used as DNA barcode in Syzygium because the divergence of the amino acids sequence is four times greater than rbcL. This study was to analyze the DNA sequence of ndhF gene on durik-durik (Syzygium sp.) origin Riau. Methods included total DNA isolation using Genomic DNA Mini Kit Plant (Geneaid), PCR, electrophoresis using $1 \%$ agarose gel, sequencing and data analysis using BioEdit, BLASTn dan MEGA 6.0 programs. The DNA sequence of durik-durik ndhF gene was $1370 \mathrm{bp}$ in size and had the higher similarity to the one of S. malaccense (99.71\%) and the lower similarity to the one of S. acuminatissimum (98.69\%). There were 26 nucleotide variations and two of them were critical nucleotides. Durik-durik formed one group with $S$. malaccense dan S. aromaticum. Nevertheless, the species name of durik-durik still unknown because there is no accessions having $100 \%$ similarity to durik-durik.

Keywords: DNA barcode, durik-durik, Kajuik Lake, ndhF gene, Syzygium.

\section{PENDAHULUAN}

Ekosistem sungai rawa banjiran (floodplain river) merupakan salah satu habitat bagi organisme perairan. Anak sungai dan danau banjiran (oxbow lake) mempunyai fungsi sebagai tempat berlindung, pemijahan serta mencari makan. Durik-durik (Syzygium sp.) merupakan salah satu vegetasi riparian yang tumbuh di sekitar danau banjiran di Sungai Kampar, Riau (Elvyra dan Yus 2010). Secara umum tumbuhan ini berada di belakang hutan payau dengan jenis tanah aluvial. Daun-daun yang gugur ke dalam danau dimanfaatkan sebagai tempat berlindung dan sumber makanan bagi ikan sungai dan danau. Buah dimanfaatkan oleh burung sebagai makanan dan juga manusia sebagai bahan tambahan masakan serta kayunya dimanfaatkan oleh masyarakat sekitar sebagai kayu bakar (Elvyra dan Yus 2010).

Penelitian sebelumnya dengan teknik identifikasi secara konvensional menggunakan karakter morfologi daun, 
tanpa ketersediaan organ bunga dan buah, telah mengelompokkan durik-durik ke dalam genus Eugenia (Elvyra dan Yus 2010). Seiring dengan kemajuan teknik identifikasi organisme yaitu dengan ditemukannya teknik identifikasi secara molekuler menggunakan potongan DNA berukuran pendek atau disebut dengan barkoding DNA (Hebert et al. 2003), maka identifikasi durik-durik dilanjutkan dengan teknik barkoding DNA. Sekuen barkode DNA yang sudah digunakan meliputi $p s b A$ trnH intergenic spacer dan ITS (Roslim et al. 2016) serta matK, rbcl, dan trnL-F intergenic spacer (Roslim et al. 2017).

Durik-durik awalnya digolongkan ke dalam genus Eugenia, famili Myrtaceae. Pengelompokkan itu didasarkan identifikasi secara morfologi tanpa dilengkapi organ bunga (Elvyra dan Yus 2010). Sekuen barkode DNA yang sudah digunakan meliputi psbA-trnH intergenic spacer dan ITS (Roslim et al. 2016) serta matK, rbcl, dan trnL-F intergenic spacer (Roslim 2019) dan menunjukkan bahwa durik-durik termasuk ke dalam genus Syzygium. Hal ini terjadi karena adanya revisi besar-besaran pada genus Eugenia menjadi Syzygium (Widodo 2011).

Syzygium termasuk ke dalam kelompok Myrtaceae (jambu-jambuan) dengan lebih dari 1.200 genus. Jumlah spesies yang banyak tersebut menjadikan spesies ini sebagai tumbuhan utama dari hutan hujan tropis di Malesia. Terdapat 300 jenis Syzygium di Indonesia dengan 60 jenisnya berada di Pulau Jawa. Syzygium banyak dimanfaatkan sebagai obat, makanan, bahan bangunan dan tanaman hias yang memiliki nilai ekonomi (Asif et al. 2013). Menurut Craven dan Biffin (2010) Syzygium merupakan salah satu kelompok Myrtaceae yang sulit diklasifikasikan karena sedikitnya karakter morfologi yang konsisten pada satu spesies dan terjadinya tumpang tindih spesies Syzygium dengan Eugenia. Bukti molekuler menunjukkan bahwa kedua genus tersebut memiliki silsilah yang berbeda (Biffin 2005, Widodo 2010).
Jumlah dan variasi yang relatif kecil dari sekuen mitokondria menjadikan alasan penggunaan DNA kloroplas pada tumbuhan dalam teknik barkoding DNA (Ingkiriwang et al. 2017). Keunggulan barkoding DNA dibandingkan identifikasi secara morfologi adalah dapat mengidentifikasi dan mengkarakterisasi berbagai spesies yang tidak dapat dibedakan secara morfologi dan spesimen sudah rusak atau organnya tidak lengkap (Hajibabaei et al. 2007).

Barkode DNA lain yang sudah digunakan pada analisis filogenetik pada Myrtaceae adalah gen $n d h F$. Gen ini mengkode enzim NADH dehydrogenase subunit 5 (ND5). Divergensi urutan asam amino gen $n d h F$ lebih besar empat kali daripada $r b c L$ pada padi dan tembakau. Semakin panjang ukuran divergensinya maka dapat lebih banyak memberikan informasi karakter dalam rekonstruksi filogeni (Kim dan Robert 1995).

Penelitian ini bertujuan mengisolasi dan menganalisis sekuen DNA pada daerah gen $n d h F$ pada durik-durik (Syzygium sp.) asal Riau. Sekuen DNA yang diperoleh pada penelitian ini merupakan yang pertama kali dilaporkan dari tumbuhan durik-durik.

\section{METODE}

Penelitian ini telah dilaksanakan bulan Oktober 2019 - Februari 2020. Sampel daun tumbuhan durik-durik diambil dari Danau Kajuik yang berada di Kecamatan Langgam, Kabupaten Pelalawan, Riau. Analisis molekuler dilakukan di Laboratorium Genetika, Jurusan Biologi, FMIPA UNRI.

\section{Bahan Penelitian}

Bahan penelitian berupa daun segar tumbuhan durik-durik (Syzygium sp.). Proses amplifikasi menggunakan dua pasang primer dengan kombinasi 748F 5'- CAG TTG CTA AAT CGG CAC AAT T-3' dengan 1318R 5'-CGA AAC ATA TAA AAT GCG GTT3' dan 1252F 5'-GAT GAA ATT MTT AAT GAT AGT TGG T-3' dengan 2063R 5'-CAT TTG GAA TTC CAT CAA TTA-3' (Biffin et al. 2006). 


\section{Isolasi DNA}

Sebanyak 0,1 gram potongan daun durik-durik dimasukkan ke dalam tabung 1,5 ml. Kemudian nitrogen cair ditambahkan secukupnya sambil terus menggerus sampel sampai halus berbentuk serbuk. Selanjutnya dilakukan ekstraksi DNA menggunakan Genomic DNA mini kit plant (Geneaid).

\section{Polymerase Chain Reaction (PCR)}

Amplifikasi gen $n d h F$ menggunakan Dream Taq DNA Polymerase (Thermo Scientific). Proses PCR dilakukan dalam volume $50 \mu \mathrm{l}$ dengan komponen sebagai berikut: 1X buffer PCR, 0,2 mM dnTPs, 2,4 $\mu \mathrm{M}$ primer forward, $2,4 \mu \mathrm{M}$ primer reverse, 2 U Taq DNA Polymerase, DNA Syzygium sp. dan aquabidestilata $\left(\mathrm{dH}_{2} \mathrm{O}\right)$. Program PCR yang digunakan terdiri dari tahapan pra-PCR pada $95^{\circ} \mathrm{C}$ selama 3 menit, denaturasi pada $95^{\circ} \mathrm{C}$ selama 30 detik, annealing selama 35 detik dengan suhu $42,5^{\circ} \mathrm{C}$ untuk primer $1252 \mathrm{~F} / 2063 \mathrm{~F}$ dan $46,6^{\circ} \mathrm{C}$ untuk primer $748 \mathrm{~F} / 1318 \mathrm{R}$, elongasi pada $72^{\circ} \mathrm{C}$ selama 1 menit dan pasca-PCR pada $72^{\circ} \mathrm{C}$ selama 10 menit. Tahap denaturasi, annealing dan elongasi dilakukan sebanyak 35 siklus.

\section{Elektroforesis}

Menggunakan mesin elektroforesis, DNA total dan produk PCR dimigrasikan di bawah pengaruh medan listrik pada gel agarose $1 \%$ untuk memperkirakan kualitas dan kuantitas DNA yang diperoleh. Gel elektroforesis menggunakan $1 \mu l$ etidium bromida sebagai pewarna pita dalam $1 \mathrm{x}$ buffer TBE (Tris-Borate-EDTA pH 8,0). Hasil elektroforesis divisualisasi menggunakan UV transiluminator (VILBER LOURMAT), kemudian difoto menggunakan kamera digital berfilter UV (OLYMPUS SP$500 \mathrm{UZ}$ ).

\section{Sekuensing}

Tabung PCR yang berisi DNA hasil amplifikasi dan primernya ditutup rapat kemudian di-seal menggunakan parafilm. Tabung tersebut dikirim ke $1^{\text {st }}$ Base Malaysia melalui PT. Genetika Science
Indonesia, Jakarta Barat untuk disekuensing. Sekuensing dilakukan secara dua arah untuk mengetahui urutan basa nukleotidanya.

\section{Analisis Data}

Data hasil sekuensing diperiksa secara visual menggunakan program BioEdit versi 7.0. Sekuen yang diperoleh diolah menggunakan program BLASTn (Basic Local Aligment Search Tool) yang diakses secara online pada situs http://www.ncbi.nlm.nih.gov/BLAST) dan MEGA versi 6.0. Sekuen DNA dari gen $n d h F$ diunduh dari aksesi yang memiliki nilai query cover $100 \%$ pada analisis BLASTn untuk keperluan analisis selanjutnya menggunakan program MEGA. Dendogram dikonstruksi dengan metode Neighbor-Joining Tree dan bootstrap 1000 ulangan.

\section{HASIL DAN PEMBAHASAN}

Isolasi DNA durik-durik (Syzygium sp.) menggunakan kit isolasi DNA Geneaid menunjukkan bahwa pita DNA yang dihasilkan utuh, tebal dan tidak smear dengan ukuran lebih besar dari $10.000 \mathrm{pb}$ (Gambar 1). Konsentrasi DNA dapat dilihat dari ketebalan pita yang dihasilkan, semakin tebal pitanya maka semakin tinggi konsentrasinya begitu pula sebaliknya. Pita tersebut layak dijadikan tempat pada proses PCR.

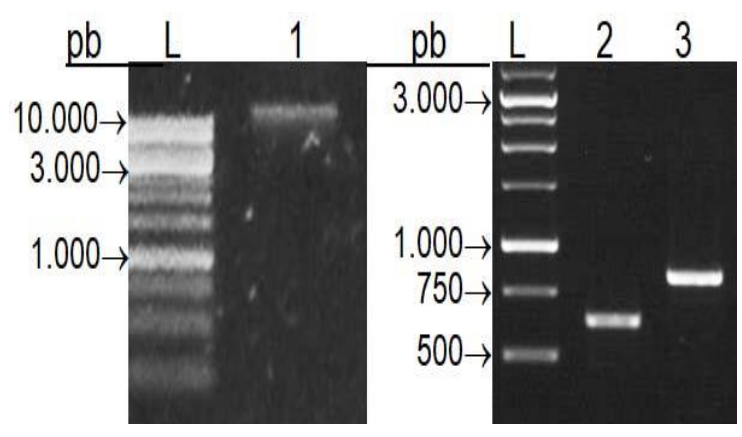

Gambar 1. Profil pita DNA total dan produk PCR dari gen $n d h F$ durik-durik. $\mathrm{L}=$ $1 \mathrm{~kb}$ DNA ladder (Thermo Scientific), $1=$ DNA total, $2=$ amplikon 748F/1318R, $3=$ amplikon 1252F/2063R, $\mathrm{pb}=$ pasang basa. 
Amplifikasi menggunakan pasangan primer 748F/1318R dan 1252F/2063R secara berturut-turut menghasilkan pita DNA berukuran $600 \mathrm{pb}$ dan $800 \mathrm{pb}$ (Gambar 1). Pita DNA yang dihasilkan tebal dan layak untuk disekuensing. Hasil sekuensing menggunakan kedua pasang primer tersebut telah disatukan dan menghasilkan sekuen DNA berukuran 1369 pb. Sekuen tersebut sudah didatarkan pada database GenBank dengan nomor registrasi MT702732 (Gambar 2).

\begin{abstract}
$>$ MT702732 Syzygium sp. DIR042 NADH dehydrogenase subunit F (ndhF) gene, partial cds; chloroplast TCGGCACAATTCCCCTTTCATGTATGGTTACCTGATGCCATGGAAGGCCC TACTCCTATTTCGGCTCTTATACATGCCGCTACTATGGTAGCAGCGGGCA TTTTTCTTGTAGCTCGACTTCTTCCTCTTTTTAGAATCATACCTTACATA ATGAATTTCATATCTTTAATAGGTATAATAACAGTATTATTAGGAGCTAC TTTAGCTCTTGCTCAAAAAGATATTAAAAGAGGTTTAGCTTATTCTACAA TGTCTCAATTGGGTTATATGATGTTAGCTCTAGGTATGGGGTCTTATCGA GCCGCTTTATTTCATTTGATTACTCATGCTTATTCGAAAGCATTGTTGTT TTTAGGATCCGGATCTATTATTCATTCAATGGAAGCTATTGTTGGATATT CTCCAGATAAAAGTCAGAATATGGTTCTTATGGGAGGTTTAAAAAAGCAT GTACCAATTACAAAAAATGCTTTTTTAGTAGGTACACTTTCTCTTTGTGG TATTCCCCCCCTTGCTTGTTTTTGGTCCAAAGATGAAATTCTTAATGCTA GTTGGTTGTATTCACCTATTTTCGCAATAATAGCTTGTTCTACAGCAGGA TTAACCGCATTTTATATGTTTCGGATCTATTTACTTACTTTTGAGGGACA TTTCAATGTTCATTTTCAAAATTATAGTGGTCAAAAAAGTCGTTCCTACT ATTCAATATCTCTATGGGGAAAAGAAGTACCAAAAACGATTAAAAACAAT TTTCTAAGTTTATTAACAATGAATAATAATGAAAGGGTTTCTTTTTTTTC GAATAAGACATATCAAATTGGTGGTAATGGGAAAAACAGGATGCGCCCTT TTATTACTATTACTCATTTTGGCACTAAAAATACTTTCTCTTATCCTCAT GAATCGGACAATACTATGCTATTTTCCATGGTTATATTAGTGCTATTTAC TTTGTTTGTTGGAGTCGTAGGAATTCCCTTTCCTTTTAATCAAGAAGGAA TTCATTTGGATATATTATCCAAATTGTTAAATCCATCTATAAACCTTTTA CATCAGAATTCAAATAATTCTGTGGATTGGTATGAATTTGTGACAAATGC AAGTTTTTCTGTCGGTATAGCTTTTTTCGGAATATTTATAGCATCTTTTT TATATAAGCCTATTTATTCATCTTTACAAAATTTGAACTTACTAAATTCG TTTTCTAAAAGAGGTCCTAATAGAATTTTTGGGGACAAAATAATAAATGT GATATATGATTGGTCATATAATCGTGGTTACATAGATGCTTTTTATACAA TATCCTTAACTCAGGGTATAAGAGGACTAGCTGAACTAATTCATTTTTTT GATAGACGAGTAATTGATG
\end{abstract}

Gambar 2. Sekuen DNA dari gen $n d h F$ durikdurik (Syzygium sp.) asal Riau.

Sekuen DNA dari gen $n d h F$ durik-durik yang diperoleh pada penelitian ini menyandikan 456 asam amino deduksi dan merupakan sekuen parsial dari gen tersebut. Rodrigues et al. (2020) melaporkan bahwa panjang sekuen DNA utuh dari gen $n d h F$ pada Eugenia selloi, yang juga merupakan anggota dari Myrtaceae, sebesar 2249 pb dan menyandikan 749 asam amino.

Hasil analisis BLASTn menunjukkan bahwa sekuen DNA dari gen $n d h F$ durikdurik memiliki kemiripan paling tinggi dengan yang dimiliki oleh $S$. malaccense, yaitu sebesar $99,71 \%$ dengan nilai query cover $100 \%$ dan nilai-E sebesar 0,0 .
Kemiripan paling rendah dengan $S$. acuminatissimum, yaitu sebesar $98,69 \%$ (Tabel 1). Pada analisis BLASTn, tidak ada aksesi yang memiliki kemiripan sampai $100 \%$ dengan durik-durik. Hal ini menunjukkan dua kemungkinan bahwa durik-durik merupakan spesies yang sudah teridentifikasi namun sekuen DNA dari gen $n d h F$-nya belum tersedia di database GenBank atau durik-durik merupakan spesies baru yang belum pernah dilaporkan.

Tabel 1. Hasil analisis BLASTn pada sekuen DNA dari gen $n d h F$ durik-durik (Syzygium sp.)

\begin{tabular}{|c|c|c|c|c|}
\hline Spesies & $\begin{array}{c}\text { Query } \\
\text { Cover } \\
(\%)\end{array}$ & $\begin{array}{l}\text { Nilai- } \\
\text { E }\end{array}$ & $\begin{array}{c}\text { Kemiripar } \\
(\%)\end{array}$ & $\begin{array}{l}\text { Nomor } \\
\text { Aksesi }\end{array}$ \\
\hline $\begin{array}{l}\text { Syzygium } \\
\text { malaccense }\end{array}$ & 100 & 0,0 & 99,71 & МТ830744.1 \\
\hline $\begin{array}{l}\text { Syzygium } \\
\text { forrestii }\end{array}$ & 100 & 0,0 & 99,63 & NC_044106.1 \\
\hline Syzygium cumini & 100 & 0,0 & 99,56 & MN095412.1 \\
\hline Syzygium jambos & 100 & 0,0 & 99,56 & MT731620.1 \\
\hline $\begin{array}{l}\text { Syzygium } \\
\text { aromaticum }\end{array}$ & 100 & 0,0 & 99,49 & NC_047249.1 \\
\hline $\begin{array}{l}\text { Syzygium } \\
\text { acuminatissimum }\end{array}$ & 100 & 0,0 & 98,69 & МТ975437.1 \\
\hline
\end{tabular}

Menurut Roslim et al. (2016) kemungkinan yang terjadi apabila sekuen DNA yang diteliti tidak menunjukkan kemiripan $100 \%$ dengan database adalah tumbuhan yang diuji sudah diketahui spesiesnya tetapi barkode DNA-nya belum tersedia di GenBank atau tumbuhan tersebut merupakan spesies baru. Oleh karena itu perlu dilakukan analisis selanjutnya dengan membandingkan morfologi durik-durik dengan semua spesies Syzygium untuk menentukan apakah durik-durik spesies baru atau bukan.

Pada penelitian ini, analisis sekuen DNA dari gen $n d h F$ menunjukkan adanya 26 variasi nukleotida yang disebabkan mutasi subtitusi. Dua diantaranya merupakan nukleotida kritis, yaitu nukleotida yang menjadi pembeda antara durik-durik dengan aksesi lain yang diteliti. Posisi nukleotida kritis berada pada nukleotida nomor 539 (yaitu $\mathrm{C}$ pada durik-durik dan $\mathrm{T}$ pada aksesi lainnya) dan 582 (yaitu A pada durik-durik dan $\mathrm{G}$ pada nukleotida lainnya) (Tabel 2). 
Tabel 2. Variasi basa nukleotida dari gen $n d h F$ pada beberapa aksesi Syzygium yang diteliti.

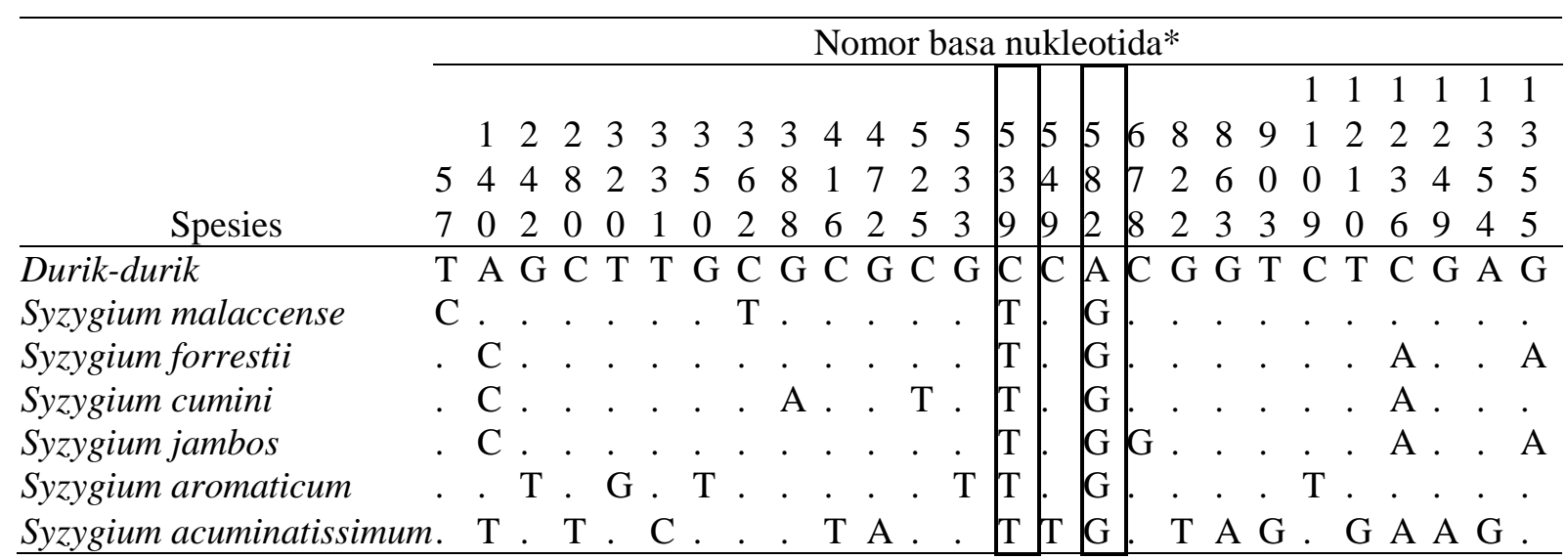

*nomor nukelotida berdasarkan sekuen DNA dari gen $n d h F$ durik-durik

Nukleotida di dalam kotak $=$ nukleotida kritis

Tabel 3. Jarak genetik antar aksesi Syzygium yang diteliti

\begin{tabular}{llllllll}
\hline \multicolumn{1}{c}{ Spesies } & \multicolumn{7}{c}{ Jarak genetik* $^{*}$} \\
\hline Durik-durik & & 0,001 & 0,002 & 0,002 & 0,002 & 0,002 & 0,003 \\
Syzygium malaccense & 0,003 & & 0,002 & 0,002 & 0,002 & 0,002 & 0,003 \\
Syzygium forrestii & 0,004 & 0,004 & & 0,001 & 0,001 & 0,002 & 0,002 \\
Syzygium cumini & 0,004 & 0,004 & 0,002 & & 0,001 & 0,002 & 0,003 \\
Syzygium jambos & 0,004 & 0,004 & 0,001 & 0,003 & & 0,002 & 0,003 \\
Syzygium aromaticum & 0,005 & 0,005 & 0,006 & 0,007 & 0,007 & & 0,003 \\
Syzygium acuminatissimum & 0,011 & 0,011 & 0,010 & 0,010 & 0,010 & 0,013 & \\
\hline
\end{tabular}

*angka di atas diagonal $=$ standar error, angka di bawah diagonal $=$ nilai jarak genetik

Penelitian sebelumnya pada durik-durik menunjukkan bahwa jumlah nukleotida kritis berdasarkan sekuen DNA dari gen matK sebanyak dua buah sedangkan berdasarkan sekuen DNA dari trnL-trnF intergenic spacer sebanyak 53 nukleotida (Roslim 2019). Hal ini menunjukkan bahwa jumlah nukleotida kritis pada sekuen DNA penyandi protein, seperti matK dan $n d h F$, lebih sedikit dibandingkan dengan sekuen DNA non penyandi protein, seperti trnLtrnF intergenic spacer.

Durik-durik memiliki jarak genetik paling dekat dengan $S$. malaccense (yaitu 0,003) dan paling jauh dengan $S$. acuminatissimum (yaitu 0,011) (Tabel 3). Semakin dekat jarak genetik menunjukkan semakin dekat kekerabatannya, begitu pula sebaliknya.

Dendrogram memperkuat hasil analisis bahwa durik-durik membentuk satu kelompok dengan S. malaccence (jambu bol, dersono atau jamaika) dan S. aromaticum (cengkih) (Gambar 3). Namun, keduanya memiliki bunga, buah dan daun yang berbeda dari durik-durik.

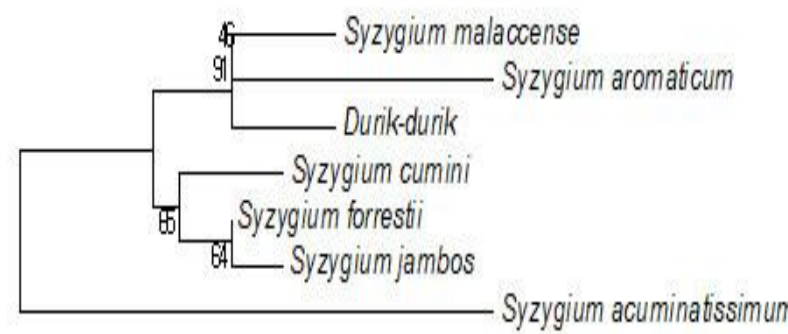

$\stackrel{0,001}{1}$

Gambar 3. Dendrogram antara beberapa aksesi Syzygium berdasarkan sekuen DNA dari gen $n d h F$.

\section{KESIMPULAN}

Sekuen DNA dari gen $n d h F$ durik-durik telah diperoleh dengan ukuran $1370 \mathrm{pb}$ dan memiliki kemiripan paling tinggi dengan 
yang dimiliki oleh $S$. malaccense $(99,71 \%)$ dan paling rendah dengan $S$. acuminatissimum (98,69\%). Terdapat 26 variasi nukleotida di antara aksesi yang diteliti dan dua diantaranya merupakan nukleotida kritis. Durik-durik membentuk satu kelompok dengan $S$. malaccense dan $S$. aromaticum. Namun demikian, nama spesies durik-durik belum dapat ditentukan karena tidak ada aksesi yang memiliki kemiripan $100 \%$ dengan durik-durik. Oleh karena itu, identifikasi dengan teknik barkoding DNA sangat bergantung pada ketersediaan sekuen target di database publik seperti GenBank.

\section{UCAPAN TERIMA KASIH}

Penelitian ini dibiayai DIPA FMIPA Universitas Riau Tahun 2020 dengan nomor kontrak 2407e/UN19.5.1.1.3/PL.01.00/2020.

\section{DAFTAR PUSTAKA}

Asif H, Khan A, Iqbal A, Khan IA, Heinze B (2013) The chloroplast genome sequence of Syzygium cumini (L.) and ITS relationship with Other Angiospermae. Tree Genetics \& Genomics 9(3): 867-877.

Biffin E (2005) Sorting out the confusion: Phylogenetics of large genera and the lessons from Syzygium (Myrtaceae). Austral. Biol. Resources Study. Biologue 30. CSIRO Plant Industry, Canberra. Internet publication: http://www.environment.gov.au/biodiver sity/abrs/publications/other/biologue/ 30/index.html\#syzygium.

Biffin E, Craven LA, Crisp M, Gadek PA (2006) Moleculer systematics of Syzygium and allied genera (Myrtaceae): Evidence from the chloroplast genom. TAXON 55 (1): 79-94.

Craven LA, Biffin E (2010) An infrageneric classification of Syzygium (Myrtaceae). Blumea 55(1): 94-99.

Elvyra R, Yus Y (2010) Ikan Lais dan Sungai Paparan Banjir di Provinsi Riau. UR press, Pekanbaru.
Harsono T, Pasaribu N, Sobir, Fitmawati, Prasetya E (2015) Variasi intraspesifik berdasarkan DNA kloroplas (cpDNA) pada Bouea macrophylla Griffit. Prosiding Seminar Nasional Biodiversitas dan Ekologi Tropika Indonesia.

Hebert PDN, Cywinska A, Ball SL, deWaard JR (2003). Biological identifications through DNA barcodes. PR Soc. London B. 270: 313-321.

Ingkiriwang M, Rudi A, Repi, Fanny NN (2017) Analisis filogeni molekuler tanaman pala (Myristica sp.) dari Tahura menggunakan gen $r b c L$ DNA kloroplas. Jurnal Sains, Matematika \& Edukasi (JSME) 5(2):138.

Kim KJ, Robert KJ (1995) Sequence evolution and the major clades in the sunflower family. Proc. Natl. Acad. Sci. 92 : 10379-10383.

Rodrigues NF, Balbinott N, Paim I, Guzman, Margis R (2020) Comparative analysis of the complete chloroplast genomes from six Neotropical species of Myrteae (Myrtaceae). Genetics and Molecular Biology 43(2): e20190302.

Roslim DI (2019) Analysis of matK, $r b c L$ and $\operatorname{trnL}$-trnF intergenic spacer sequences on durik-durik (Syzygium sp). J. Phys.: Conf. Ser. 1351: 012023.

Roslim DI, Putri N, Herman, Roza E (2016) Identification of Durik-durik Plant (Syzygium sp.) Using the psbA-trnH Intergenic Spacer and ITS Region. Transaction of Persatuan Genetik Malaysia $3: 11-16$.

Widodo P (2010) Enumeration of Sumatran Syzygium (Myrtaceae). Unpublished Dissertation. Institut Pertanian Bogor. Bogor.

Widodo P (2011) Syzygium of Sumatra. The Free-Petalled Species. Las Vegas: Lambert Academic Publishing. 